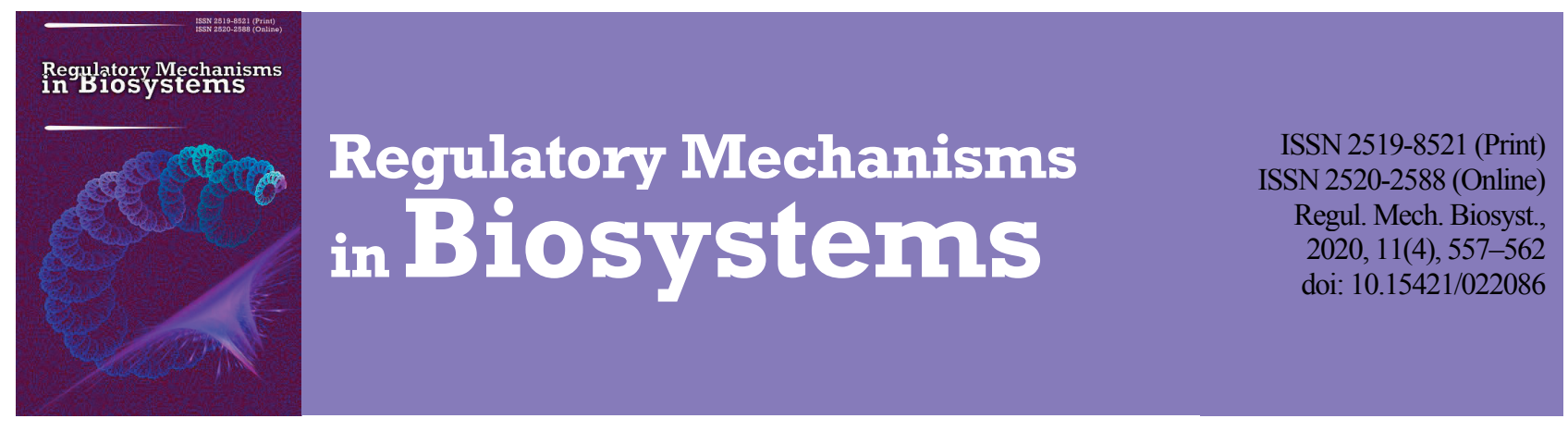

\title{
Amlodipine modulation of analgesic effect of non-steroidal anti-inflammatory drugs in rheumatoid arthritis, comorbid with arterial hypertension
}

\author{
N. M. Seredynska*, V. I. Kornienko**, D. V. Kibkalo**, O. S. Suvorova*, O. M. Marchenko*, O. V. Ladogubets** \\ *Institute of Pharmacology and Toxicology, The National Academy of Medical Sciences of Ukraine, Kyiv, Ukraine \\ **Kharkiv Zooveterinary Academy, Kharkiv, Ukraine
}

Article info

Received 21.10.2020

Received in revised form 16.11.2020

Accepted 18.11.2020

Institute of Pharmacolog and Toxicology,

The National Academy

of Medical Sciences

of Ukraine, Antona

Zcedica st, 14,

Kyiv, 03057, Ukraine.

Tel.: +38-067-726-00-96

E-mail:onmi@i.ua

Kharkiv Zooveterinary

Academy, Academic st, 1

smt Mala Danylivka,

62341, Ukraine.

Tel.: +38-057-635-74-73.

E-mail:

iinfo@hdzva.edu.ua

\section{Introduction}

Comorbidity is an important problem of modern medicine. The causes of comorbidity are the anatomical proximity of the affected organs, joint pathogenesis, cause-effect relations or accidental combination of diseases (Kolomoyets \& Vashenyak, 2012; Turesson, 2016; Oganov et al., 2017). Most elderly and senile patients have several combined pathologies of different organs and systems that compete in prognostic value. Comorbidity is a common phenomenon in young patients, including the age up to 20 years. One and the same patient can be diagnosed with 3-5 different diseases and their number increases with age (Rudyuk, 2012; Kłodziński, 2018; Furman et al., 2019).

Rheumatic diseases, in particular rheumatoid arthritis (RA), are one of the main medical and socio-economic problems of modern rheumatology due to their prevalence, severe course of the disease, insufficient efficacy of pharmacological correction, etc. The disease is characterized by severe damage to the joints with destruction of bone tissue, a significant reduction in quality of life. RA treatment is based on a pathogenetic approach (Shuba et al., 2018). However, to achieve a rapid effect, accompanied by relief of the patient's condition and suffering, pain attenuation, using basic drugs for the RA treatment, is not always possible due to the side effects of these drugs, due to the gradual manifestation of their activity, drug intolerance, etc.
Seredynska, N. M., Kornienko, V. I., Kibkalo, D. V., Suvorova, O. S., Marchenko, O. M., \& Ladogubets, O. V. (2020). Amlodipine modulation of analgesic effect of non-steroidal anti-inflammatory drugs in rheumatoid arthritis, comorbid with arterial hyperten-

(1) Bechanisms in Biosystems, 11(4), 557-562. doi:10.15421/022086 in different periods of inflammation against the background of hypertension should be studied. Using the model of adjuvant arthritis means of the "tail flick" test Hypertension was caused by salt load with $1 \%$ sodium chloride solution for drinking with free access to it Adjuvant arthritis was induced by the introduction of complete Freund's adjuvant into the plantar aponeurosis of the hind limb of each animal with the established arterial hypertension. Against the background of arterial hypertension and comorbid pathology, there was an in threshold of pain sensitivity observed in rats, which indicated the development of hypoalgesia. When combined, amlodihypertension. The antinociceptive effect of diclofenac with amlodipine and celecoxib with amlodipine exceeded the analgesic effect of account under the conditions of prescribing drugs belonging to the studied pharmacotherapeutic groups. It is likely that the use of dicloThe use of nimesulide to achieve an analgesic effect in the recurrence of rheumatoid arthritis against the background of hypertension is appropriate in the acute period and in the period of the inflammatory process attenuation. A highly selective coxib group cyclooxygehas developed against the background of arterial hypertension.

Keywords: rheumatoid arthritis; arterial hypertension; amlodipine; non-steroidal anti-inflammatory drugs; analgesic effect.

Unfortunately, most patients seek medical advice when RA is already chronic, accompanied by severe pain, swelling of the extremities, deformed joints, which often leads to disability. The complexity of RA treatment, insufficient efficacy and safety of the treatment are due to the fact that most disease-modifying drugs classified as basic therapy drugs (mainly immunosuppressants of different groups), significantly affecting the course of RA and providing long-term remission, often have side effects. In addition, the chronic course of the disease and the late (as a rule) treatment onset necessitates therapy aimed at eliminating the main symptoms of the disease, using nonsteroidal anti-inflammatory drugs (NSAIDs), which are rated the most important symptomatic drugs, particularly in rheumatic diseases and are "the first-line" drugs (Karateev et al., 2018).

The rationale for the prescription of NSAIDs is their ability to eliminate pain and inflammation, reduce temperature (overall and local). At the same time, the side effects of NSAIDs are a serious limitation in their use and doctors are cautious in choosing a drug of this group. Until recently, it was believed that the most common side effect of NSAIDs is lesion of the gastrointestinal tract. At the same time, the data of modern studies indicate that cardiovascular side effects of NSAIDs are observed to be three times more frequent than their gastrointestinal effect (Shuba et al., 2018). Some researchers believe that the cardiotoxic effects of NSAIDs are more dangerous than the gastrotoxic ones (Combe et al., 2009; Fosbol et al., 2010; 
Moore et al., 2013). Therefore, the use of NSAIDs requires knowledge not only about their mechanism of action, but also about possible side effects, including risk factors to the cardiovascular system, in particular, and ways of their pharmacological correction (Trelle et al., 2011; Olyulin, 2017; Haddani, 2019). Quite frequently against the background of RA there occur diseases of the cardiovascular system or, conversely, RA appears and develops against the background of pre-existing cardiac pathology (Dougados et al., 2015; Dougados, 2016; Turesson, 2016; Mantel et al., 2017). Comorbidity of RA with cardiac diseases necessitates constant monitoring of the patient's condition, pharmacological correction to prevent complications and fatalities (Hitchon et al., 2016; Widdifield et al., 2018; Daïen et al., 2019; Luque, 2019; Roubille, 2019).

One of the threatening side effects of NSAIDs is development of hypertension (AH) (Gromova \& Myasoedova, 2014; Karateev, 2014; Mantel et al., 2017), which justifies additional prescription of appropriate drugs. The hypertensive effect of NSAIDs is due to several mechanisms, including a decrease in natriuresis due to inhibition of filtration and enhancement of proximal tubular reabsorption of sodium ions, decreased glomerular filtration and renal blood flow, activation of the reninangiotensin system, increased renal resistance through inhibiting synthesis of prostaglandins which ensure blood flow, increased norepinephrine release from nerve endings, etc.

One of the most common cardiovascular risk factors in RA is also hypertension (Nikitina et al., 2015; Grinyuk \& Zakharov, 2019). The level of blood pressure does not correlate with the RA activity, but it is associated with various characteristics of pain, which requires the attention of clinicians and, certainly, appropriate pharmacological correction (Myasoedova, 2012; Antivalle et al., 2013).

In fact, RA can cause hypertension, as proven by clinical and experimental studies, or RA develops against the background of hypertension and frequently treatment with cyclooxygenase inhibitors is complicated by elevated blood pressure (Trelle et al., 2011; Wojciechowska et al., 2013; Himion \& Klimas', 2015).

Pharmacotherapy of the above pathological conditions (RA and AH) is an extremely important problem of medicine, and the possibility of complete recovery of patients, in fact, is not recorded by clinicians. Treatment of $\mathrm{AH}$, as well as rheumatic diseases, is based on a pathogenetic approach. This information indicates the ways of pharmacological correction of RA, comorbid with $\mathrm{AH}$, and requires the selection of drugs belonging to different pharmacotherapeutic groups that can suppress inflammation, eliminate or at least reduce the pain syndrome, as well as influence stabilization of the cardiovascular system, in particular, normalizing blood pressure. The need for long-term use of analgesics and anti-inflammatory drugs in RA is due not only to the desire to improve the patient's condition and quality of life, but also due to the fact that prolonged pain can also lead to complications in the cardiovascular (and other) system and increase the risk of hypertension and development of other cardiac diseases (myocardial infarction, angina, coronary heart disease, etc.) by activating the sympathetic nervous system. Treatment of chronic pain and inflammation in $\mathrm{RA}$, even when the condition that is not comorbid with $\mathrm{AH}$, requires a careful approach to the choice of NSAIDs and constant blood pressure monitoring.

Features of, in fact, action and manifestation of side effects of each NSAID in different pathological conditions are largely due to the selectivity of individual drugs to different types of cyclooxygenase (COG) (Karateev, 2012; Zhuravleva et al., 2016; Naumov et al., 2019).

It is believed that in frequent and regular use of NSAIDs, including use against the background of RA associated with $\mathrm{AH}$, preference should be given to the prescription of calcium antagonists (and blockers of type II angitensin receptors), which in real clinical practice is far from always performed (Rodionov, 2013).

Previous experimental RA studies revealed, in addition to hypotensive, analgesic and anti-inflammatory effects of amlodipine (AM) and various cardiotropic effects of NSAIDs with different selectivity to different types of COX against the background of RA (Seredinskaya et al., 2013; Seredinskaya \& Pavlyuk, 2013; Seredynska et al., 2013). The results of the performed studies permitted us to suggest that due to the ability of calcium antagonists of the dihydropyridine series (namely, AM) to cause an antispasmodic effect, their analgesic activity is manifested.
This information indicates possible ways of pharmacological correction of RA, comorbid with $\mathrm{AH}$, and requires the selection of drugs belonging to different pharmacotherapeutic groups that can suppress inflammation, reduce pain, and influence the stabilization of the cardiovascular system, in particular, normalize blood pressure. Given that to eliminate the prohypertensive effect of NSAIDs, it is recommended to use AM as a drug that leads to a gradual decrease in blood pressure without changing the heart rate, and also considering the data on its own analgesic activity, manifested against the background of independent experimental RA (adjuvant arthritis - AA) (Seredinskaya et al., 2013), there is a prediction about the possibility of modulating the analgesic effect of NSAIDs, different in selectivity to $\mathrm{COX}$, when used in combination with AM against the background of experimental RA combined with $\mathrm{AH}$.

The relevance of this development lies in optimizing the choice of drugs of the NSAIDs group for possible combined use with AM, which can be effectively and safely be applied against the background of comorbid pathology (RA with $\mathrm{AH}$ ) to correct the inflammatory process, in particular, providing an analgesic effect.

For that purpose, a study of the diclofenac (DC), nimesulide (NM) and celecoxib (CC) analgesic activity under the conditions of experimental RA combined with $\mathrm{AH}$ was performed.

\section{Materials and methods}

All experimental procedures were carried out in compliance with the international animal welfare requirements set out by the European Convention for the Protection of Vertebrate Animals (Directive 86/609/EC, European Convention for the Protection of Vertebrate Animals used for Experimental and Other Scientific Purposes: Council of Europe - Strasbourg, 1986) and are used for experimental and other scientific purposes. The rules of euthanasia and disposal of dead animals met the requirements of preclinical practice.

The experiments were performed on mature nonlinear white rats of both sexes with a starting weight of $160.0 \pm 3.3 \mathrm{~g}$, which were kept on a standard diet in the vivarium under the conditions of free access to food and water. After acclimatization of the animals (14 days) and randomization, the groups of rats were identified, each of them including a certain number of rats of each sex.

Experiments to study pharmacological activity of each type of NSAID were performed on 11 groups of animals. Group 1 included rats (group of intact animals, $\mathrm{n}=15$ ) which were kept in the laboratory in cages on a normal diet under the conditions of free access to food and water for the same period as animals of other groups. Group 2 includes rats of the control group (21 animals), in which RA was induced by administration of complete Freund's adjuvant (FA) (Saratikov et al., 1983; Darren etal., 2013; Choudhary, 2018).

In the animals (200 rats, salt drink with free access to it for 21 days) arterial hypertension was induced by salt loading (Bohr \& Dominiczak, 1991; Badyal et al., 2003; Dornas \& Silva, 2011).

After the AH formation (21 days), rats were selected in which an increase in blood pressure by $8-20 \%$ was registered. These animals were divided into groups, among which one group (the third) included animals with $\mathrm{AH}(\mathrm{n}=15$; control of hypertension). Group 4 included animals which were administered FA (21 days of salt load, $n=15)$, thus causing comorbid pathology (CP) - AH with AA (Seredynska et al., 2019). Groups 5, 6, 7 and 8 included 15 animals each, which, against the background of RA combined with AH development, were administered DC, NM, CC and $\mathrm{AM}$, respectively. The following groups included 15 rats, each, which against the background of CP, were administered DC with AM (group 9), NM with AM (group 10) or CC with AM (group 11). The salt load was maintained during the RA development period itself, i. e. for another 60 days after the FA administration. The drugs under study - DC, $50 \mathrm{mg}$ tablets; NM, 100 mg tablets; CC (Revmoxib), 100 mg capsules; AM, tablets of $10 \mathrm{mg}$ - were administered through a special metal probe into the stomach in $1 \%$ starch suspension in therapeutically effective doses listed for animals of the appropriate species: $8,15,15$ and $1.5 \mathrm{mg} / \mathrm{kg}$ of animal body weight, respectively. The choice of NSAIDs is due, as noted above, to varying degrees of selectivity to COX, fairly high, clinically proven efficacy, studied safety and clinical application variety (Kozachok \& 
Selyuk, 2010; Mattia et al., 2010; Karateev, 2011; Skorokhodov \& Polyanskaya, 2013; Knyazkova, 2014; Eliseev, 2016; Shuba et al., 2018).

The studied NSAIDs and AM under the monotherapy conditions were administered daily, once a day. Under the conditions of combined therapy using drugs of different pharmacotherapeutic groups (AM with DC, or AM with $\mathrm{NM}$, or $\mathrm{AM}$ with $\mathrm{CC}$ ) medicinal products were administered alternately at intervals of 30 minutes. The duration of the animals' observation was 81 days after the start of AH simulation, of these 60 days having passed after the FA introduction, due to the phasal nature of RA.

The analgesic activity of drugs was studied by the "tail flick" test (irritation of the proximal part of the tail was carried out by focusing the infrared beam) and assessed by the pain sensitivity threshold (c) using the Ugo Basil (Italy) analgesimeter with determining the above initial index in all animals and further formation of groups only including those animals, whose initial value of the index ranging 4-16 s was registered (Seredynska et al., 2014). The study was performed in the dynamics within the terms which corresponded to certain stages of the comorbid process development. Thus, registration of analgesic activity was performed in intact animals before the start of $\mathrm{AH}$ modeling, then - on the 7th, 14th, 21st days of $\mathrm{AH}$ formation, and then - on the 7th, 14th, 28th, 42nd and 60th days after FA administration. It is on (7-14th) days that the acute period of AA occurs, when maximal local reaction to the FA administration is observed, 14-35-42 days are the terms when the AA generalization is taking place, the period from 42 to 60 days is characterized as the attenuation of the pathological process.

The results were statistically analyzed in Statistica Software (Stat Soft Inc., USA). We calculated the mean arithmetic value and the standard error. The differences between the values in the control and experimental groups were determined using ANOVA, where the differences were considered reliable at $\mathrm{P}<0.05$.

\section{Results}

In the intact animals there were irregular and statistically insignificant changes in the threshold of pain sensitivity. During the AH formation (21 days), which was modeled by salt loading, there was an increase in the threshold of pain sensitivity in white rats by $24-27 \%$ compared to the baseline, which is evidence of reduced pain sensitivity in animals (Table 1).

Table 1

Threshold of pain sensitivity $(\mathrm{x} \pm \mathrm{SE}, \mathrm{s})$

in white rats with arterial hypertension formation by salt loading

\begin{tabular}{lcccc}
\hline \multirow{2}{*}{$\begin{array}{c}\text { Group, number } \\
\text { of animals (n), } \%\end{array}$} & \multicolumn{4}{c}{ Observation term, day } \\
\cline { 2 - 5 } & baseline data & 7 & 14 & 21 \\
\hline Intact & $9.39 \pm 0.3$ & $11.7 \pm 1.1$ & $9.8 \pm 1.1$ & $9.07 \pm 0.2$ \\
$\mathrm{n}$ & 15 & 15 & 15 & 15 \\
$\%$ (compared to baseline) & 100 & 124.5 & 14.3 & 96.5 \\
$\mathrm{AH}$ & $9.07 \pm 0.02$ & $11.6 \pm 0.02 *$ & $11.5 \pm 0.02 *$ & $11.8 \pm 0.3^{* \#}$ \\
$\mathrm{n}$ & 200 & 200 & 200 & 200 \\
$\%$ (compared to baseline) & 100 & 127 & 124 & 127 \\
\hline
\end{tabular}

Notes: ${ }^{*}-\mathrm{p}<0.05$ compared to baseline values in animals of this group, ${ }^{\sharp}-\mathrm{P}<0.05$ compared to the values in intact animals for the corresponding observation period, by ANOVA method with Bonferroni correction.

During the next period of observing animals with $\mathrm{AH}$, which continued to be kept in the salt load conditions for another 60 days (total salt load period was 81 days), no significant changes in the threshold of pain sensitivity were observed compared to those recorded for 21 days (Table 2). Fluctuations in the value of the of pain sensitivity threshold in the direction of increase by $12 \%$ was observed at the beginning, and in the direction of decrease by $13 \%$ - at the end of the AA attenuation period against the background of $\mathrm{AH}$.

Table 2

Pain sensitivity threshold $(\mathrm{s}, \mathrm{x} \pm \mathrm{SE}, \mathrm{n}=15)$ and its change degree (\%) compared to baseline data in rats treated with diclofenac, nimesulide, celecoxib and amlodipine

\begin{tabular}{|c|c|c|c|c|c|c|}
\hline \multirow{2}{*}{$\begin{array}{c}\text { Group, } \\
\%\end{array}$} & \multicolumn{6}{|c|}{ Observation term, day } \\
\hline & Baseline data & $7(21+7)$ & $14(21+14)$ & $28(21+28)$ & $42(21+42)$ & $60(21+60)$ \\
\hline Intact & $9.4 \pm 0.02$ & $9.6 \pm 0.3$ & $9.8 \pm 0.3$ & $8.9 \pm 0.1$ & $9.4 \pm 0.2$ & $9.7 \pm 0.4$ \\
\hline AA & $9.1 \pm 0.02$ & $3.98 \pm 0.02^{*}$ & $3.39 \pm 0.5$ & $5.47 \pm 0.7^{*}$ & $5.7 \pm 0.5^{*}$ & $8.9 \pm 0.6$ \\
\hline$\%$ & 100 & 43.9 & 37.4 & 60.3 & 63 & 98.1 \\
\hline $\mathrm{AH}$ & $11.8 \pm 0.1^{\#}$ & $11.2 \pm 1.1^{\#}$ & $10.7 \pm 1.0^{\sharp}$ & $10.7 \pm 0.8^{\#}$ & $11.3 \pm 1.6^{\#}$ & $11.1 \pm 0.4^{\sharp}$ \\
\hline $\mathrm{CP}$ & $11.6 \pm 0.3$ & $10.9 \pm 1.2^{\#}$ & $12.4 \pm 1.1^{* \sharp}$ & $11.8 \pm 1.2^{*}$ & $12.7 \pm 1.3^{\#}$ & $11.5 \pm 1.3^{\#}$ \\
\hline$\%$ & 100 & 94 & 106.9 & 101.7 & 109.5 & 99.1 \\
\hline $\mathrm{CP}+\mathrm{DC}$ & $11.3 \pm 0.9$ & $15.8 \pm 1.0^{* \text { 牡 }}$ & $12.6 \pm 1.3^{\#}$ & $9.5 \pm 1.9^{\#}$ & $11.8 \pm 1.9^{\sharp}$ & $12.7 \pm 0.6^{\text {\#吅 }}$ \\
\hline$\%$ & 100 & 139.8 & 111.5 & 84.1 & 104.4 & 112.4 \\
\hline $\mathrm{CP}+\mathrm{NM}$ & $11.6 \pm 0.6$ & $12.7 \pm 1.3^{* \#}$ & $13.2 \pm 1.2^{\text {* }}$ & $12.6 \pm 0.9^{\text {*\# }}$ & $14.7 \pm 1.7^{\text {*\# }}$ & $11.1 \pm 2.1$ \\
\hline$\%$ & 100 & 109.5 & 113.8 & 108.6 & 126.7 & 95.7 \\
\hline $\mathrm{CP}+\mathrm{CC}$ & $11.9 \pm 0.3$ & $15.9 \pm 1.2^{* \neq \Delta \triangle}$ & $12.9 \pm 1.3$ & $14.9 \pm 0.9^{* \neq \Delta \triangle}$ & $14.0 \pm 1.3$ & $12.6 \pm 1.2$ \\
\hline$\%$ & 100 & 133.6 & 108.4 & 125 & 117.6 & 105.9 \\
\hline $\mathrm{CP}+\mathrm{AM}$ & $11.5 \pm 0.8$ & $13.1 \pm 1.4^{\#}$ & $12.1 \pm 0.8^{\sharp}$ & $11.3 \pm 0.5^{\sharp}$ & $16.3 \pm 0.7^{\text {地 }}$ & $10.1 \pm 0.7$ \\
\hline$\%$ & 100 & 113.9 & 105.2 & 98.3 & 141.7 & 88 \\
\hline $\mathrm{CP}+\mathrm{DC}+\mathrm{AM}$ & $11.9 \pm 0.6$ & $16.8 \pm 2.0^{* \text { * 扣 }}$ & $17.6 \pm 2.0^{\# \pm \lambda}$ & $18.4 \pm 3.1^{*} \stackrel{* t 口}{x}$ & $17.0 \pm 3.6^{* \# \lambda}$ & $19.1 \pm 3.6^{\#-x}$ \\
\hline$\%$ & 100 & 141 & 147.9 & 154.6 & 142.9 & 160.5 \\
\hline $\mathrm{CP}+\mathrm{NM}+\mathrm{AM}$ & $11.3 \pm 0.8$ & $13.7 \pm 1.3^{\text {*\# }}$ & $13.2 \pm 1.4^{\#}$ & $12.7 \pm 0.9^{\sharp}$ & $15.7 \pm 2.4^{* \#}$ & $10.4 \pm 0.8^{\#}$ \\
\hline$\%$ & 100 & 121.2 & 116.8 & 112.4 & 138.9 & 92.1 \\
\hline $\mathrm{CP}+\mathrm{CC}+\mathrm{AM}$ & $11.8 \pm 0.3$ & $16.5 \pm 1.2^{\text {米扣 }}$ & $16.9 \pm 1.0^{\#-x}$ & $15.6 \pm 0.9^{\text {*扣 }}$ & $15.2 \pm 1.2^{\#-x}$ & $10.3 \pm 3.1$ \\
\hline$\%$ & 100 & 139.8 & 143 & 132 & 128.8 & 87.3 \\
\hline
\end{tabular}

Notes: * $-\mathrm{P}<0.05$ compared to the baseline data in rats of this group, ${ }^{\sharp}-\mathrm{P}<0.05$ compared to the data in animals with $\mathrm{AA}$ only, ${ }^{\Delta}-\mathrm{P}<0.05$ compared to the data in animals with hypertension only, ${ }^{\square}-\mathrm{P}<0.05$ compared to the data in animals with combined pathology, ${ }^{\chi}-\mathrm{P}<0.05$ compared to data in animals treated with appropriate NSAIDs only, ${ }^{\&}$ - in parentheses indicates the total period of animals' observation (from the beginning of the AH formation), other numbers indicate the period after the FA administration, ${ }^{\partial}-$ animals of this group were observed only for 60 days after the FA administration (rats without AH), by ANOVA method with Bonferroni correction.

Against the background of AA, a significant decrease in the threshold of pain sensitivity in the rats was registered from the first days after the lesion. This index in the acute period of AA - 7-14th days - decreased by $56.1-62.6 \%$ compared to baseline and values in intact animals. During $28-49$ th days, the pain sensitivity threshold was lower by $37-38 \%$ than baseline, indicating an increase in pain sensitivity in white rats against the background of AA. Restoration of the pain sensitivity threshold occurred with the attenuation of the pathological process.
It should be noted that the baseline data of the pain sensitivity threshold in rats with $\mathrm{AH}$ of all subsequent experimental groups correspond to the values recorded in animals with formed $\mathrm{AH}$ (21 days from the beginning of salt load; see Table 2). In rats with CP, the pain sensitivity threshold was higher compared to the baseline (almost 7-10\%) at all stages of observation, except for the 7th and the 60th days of AA induction, which is an evidence of hypoalgesia against the background of combined pathology, as in animals with AH only. 
The use of DC led to a statistically significant increase in the pain sensitivity threshold by almost $40 \%$ in the first 7 days after the FA administration against the background of $\mathrm{AH}$. The respective efficacy of this drug was observed for 14 days from the induction of AA and during the period of inflammatory process attenuation (increase in the pain sensitivity threshold by $11.5 \%$ and $12.0 \%$, respectively). In other terms, DC did not significantly affect the pain sensitivity of animals with combined pathology, compared to the untreated animals with comorbid condition.

The increase in the pain sensitivity threshold (almost 9-14\%) compared to baseline in rats under the action of NM occurred both in the acute period of $\mathrm{AA}$ development against the background of $\mathrm{AH}$, and in the period of its attenuation, the greatest $(27 \%, \mathrm{P}<0.05)$ change of this index being recorded on the 42nd day. Compared to this index in animals with AA only, changes in the pain sensitivity threshold were significant within 60 days after the FA administration. The selective COX-2 NM inhibitor slightly reduced pain sensitivity (by $16-19 \%$ at different stages of observation) in rats against the background of $\mathrm{CP}$ compared to the values in animals of the control group with combined pathology.

Against the background of $\mathrm{CP}, \mathrm{CC}$ significantly increased the pain sensitivity threshold in rats both in the acute period of inflammation and during the inflammatory process manifestation (in general, within 28 days after FA administration), and this change was significant compared to that recorded in untreated animals with $\mathrm{AH}$ only and in untreated animals with $\mathrm{CP}$. Thus, $\mathrm{CC}$ significantly reduced pain sensitivity in animals against the background ofAH, combined with experimental RA, in the acute period of AA and in the period of the actual inflammatory process manifestation.

The greatest effect of AM on the pain sensitivity threshold in rats with $\mathrm{CP}$ was observed in the acute period of the inflammatory process $(14 \%$; the 7 th day) and at the beginning of the attenuation period ( $42 \%$; the 42 nd day), and changes in the pain sensitivity threshold on the 42nd day after FA administration were reliable compared to this index in animals of the control group with $\mathrm{CP}$.

The combined use of DC with AM against the background of CP led to a significant increase in the pain sensitivity threshold at all stages of the inflammatory process by $(41-61 \%)$ compared to the baseline. These changes were reliable compared to those recorded in untreated animals with $\mathrm{AH}$, as well as in rats with $\mathrm{CP}$ and, naturally, in rats with AA. Moreover, $\mathrm{AM}$ when used in combination with $\mathrm{DC}$ significantly reduced pain sensitivity in rats with comorbid condition, compared to animals treated with DC only, not particularly in the acute period of the inflammatory process, but throughout the experimental RA development.

Thus, AM enhanced the analgesic effect of DC against the background of AH combined with experimental RA, under the condition of its combined use with the specified NSAID. In fact, AM significantly reduces pain sensitivity in animals with comorbid condition in its combined use with DC. Under the conditions of AM combined use with NM there was a decrease in pain sensitivity by almost $12-40 \%$ at different observation terms in animals; the most significant, as with the use of AM only (and equivalent to the latter), was during the pathological process attenuation (42nd day). This fact permits us to assume that AM against the background of $\mathrm{CP}$ does not significantly increase the analgesic effect of NM.

An increase in the threshold of pain sensitivity, significant $(\mathrm{P}<0.05)$ not only compared to the baseline, but to the values recorded in rats with $\mathrm{CP}$, was registered in animals under the conditions of CC combined use with $\mathrm{AM}$ in the acute period and during the generalization of inflammatory process induced by FA, against the background of $\mathrm{AH}$ (up to the 28th day).

\section{Discussion}

In AH simulation, a statistically significant increase in the pain sensitivity threshold in intact animals was confirmed. The results are consistent with experimental and clinical studies dedicated to the correlation between pain threshold and blood pressure, which indicate that $\mathrm{AH}$ is accompanied by the development of hypoalgesia (Dworkin et al., 1979; Grinyuk et al., 2016). The pathophysiological mechanisms of this phenomenon are of interest to researchers and continue to be elucidated in experimental and clinical studies (Grinyuk \& Zakharov, 2019).

It is reported that this is due to the general risk factors for $\mathrm{AH}$ and pain syndrome in musculoskeletal disorders (age of 55 years and older, over- weight, hypokinesia, diabetes, etc.). It is possible that hypoalgesia in $\mathrm{AH}$ is due to the fact that the systems of blood pressure regulation and pain threshold are anatomically connected, and the main structures of the CNS that regulate the pain stimulus also affect blood pressure. It is believed that the increase in blood pressure due to pain causes ascending afferentation from the baroreceptors of the vascular wall. Sensory input from them stimulates the antinociceptive centers of the brainstem (Saavedra, 1981; Wendel \& Bennett, 1981; Sitsen \& Jong, 1983; Ogawa et al., 1991).

The known fact of hypoalgesia development is confirmed by results of our studies in simulation of a comorbid pathological condition - $\mathrm{AH}$ associated with AA. Against the background of CP there is an increase in the pain sensitivity threshold in rats. Obviously, this fact is particularly due to $\mathrm{AH}$. The increase in pain sensitivity to the FA administration is offset by a pathological condition $-\mathrm{AH}$. The mechanism of this phenomenon is not known for sure and requires a special well-planned study.

Data on the analgesic effect of NSAIDs different in selectivity to COX can, apparently, be taken into account in terms of prescribing drugs of the studied pharmacotherapeutic groups. Probably, the use of DC for analgesia against the background of $\mathrm{AH}$ is appropriate only in the acute period of RA. The use of NM to achieve an analgesic effect in the conditions of RA exacerbation against the background of hypertension is appropriate in the acute period and in the period of $\mathrm{AA}$ attenuation against the background of $\mathrm{AH}$. A selective COX-2 inhibitor of the $\mathrm{CC}$ coxib group can reduce pain during the acute period of AA and during the manifestation of the inflammatory response that has developed against the background of $\mathrm{AH}$.

The use of AM with DC or AM with CC for the purpose of analgesia significantly increases the efficacy of these NSAIDs against the background of $\mathrm{AH}$ combined with $\mathrm{AA}$, while $\mathrm{AM}$ does not significantly increase the analgesic effect of NM, i.e. analgesic effect of DC with AM and $\mathrm{CC}$ with $\mathrm{AM}$ is higher than that registered for the use of $\mathrm{NM}$ with $\mathrm{AM}$.

The results obtained should be confirmed by clinical trials. At the same time, clinicians can use the information provided in this paper to optimize the combined use of NSAIDs with different selectivity to COX with dihydropyridine calcium antagonists against different periods of the comorbid state.

\section{Conclusion}

Against the background of a comorbid condition (arterial hypertension associated with adjuvant arthritis), pain sensitivity in rats was reduced. Diclofenac increased the pain sensitivity threshold in the acute period and at the end of the arthritis attenuation period, which developed against the background of arterial hypertension, and did not change the pain sensitivity at other stages of the inflammatory process. The analgesic activity of nimesulide increased after the 42nd day of adjuvant arthritis against the background of arterial hypertension.

Celecoxib reduced pain in the acute period of rheumatoid arthritis and in the manifestation of the inflammatory response that developed against the background of arterial hypertension, and at the same time preponderated in analgesic activity over diclofenac and nimesulide against the background of the comorbid condition.

Amlodipine enhanced the analgesic activity of diclofenac during 60 days of observation, slightly increased the analgesic effect of nimesulide - up to the 42nd day, the effect of celecoxib - in the acute period and the period of adjuvant arthritis manifestation against the background of AH. The analgesic effect of diclofenac with amlodipine and celecoxib with amlodipine was higher than that recorded with the combined use of nimesulide with amlodipine against the background of comorbid pathology.

\section{References}

Antivalle, M., Chevallard, M., Battellino, M., Batticciotto, A., Chiara, D. M., Mutti, A., Rigamonti, F., Varisco, V., Bongiovanni, S., Atzeni, F., \& Sarzi-Puttini, P. (2013). Reduced response to biologic treatments in rheumatoid argritis patients affected by arterial hyperthension. Arthritis and Rheumatology, 65(10), 462-465.

Badyal, D. K., Lata, H., \& Dadhich, A. P. (2003). Animal models of hypertension and effect of drugs. Indian Journal Pharmacology, 35, 349-362. 
Bohr, D. F., \& Dominiczak, A. F. (1991). Experimantal hypertension. Hypertension, $17(1), 39-44$.

Choudhary, N., Bhatt, L. K., \& Prabhavalkar, K. S. (2018). Experimental animal models for rheumatoid arthritis. Immunopharmacology and Immunotoxicology, 40(3), 193-200.

Combe, B., Swergold, G., McLay, J., McCarthy, T., Zerbini, C., Emery, P., Connors, L., Kaur, A., Curtis, S., Laine, L., \& Cannon, C. P. (2009). Cardiovascular safety and gastrointestinal tolerability of etoricoxib vs diclofenac in a randomized controlled clinical trial (The MEDAL study). Rheumatology, 48(4), 425-432.

Daïen, C. I., Tubery, A., Beurai-Weber, M., du Cailar, G., Picot, M. C., Jaussent, A., Roubille, F., Cohen, J. D., Morel, J., Bousquet, J., Fesler, P., \& Combe, B. (2019). Relevance and feasibility of a systematic screening of multimorbidities in patients with chronic inflammatory rheumatic diseases. Joint Bone Spine, 86(1), 49-54.

Darren, L. A., Ashley, M. M., Iain, B. M., \& Foo, Y. L. (2013). Animal models of rheumatoid arthritis. European Journal of Immunology, 39(8), 2040-2044.

Dornas, W. C., \& Silva, M. E. (2011). Animal models for study of arterial hypertension. Journal of Biosciences, 36(4), 731-737.

Dougados, M. (2016) Comorbidities in rheumatoid arthritis. Current Opinion in Rheumatology, 28(3), 282-288.

Dougados, M., Soubrier, M., Perrodeau, E., Gossec, L., Fayet, F., Gilson, M., Cerato, M. H., Pouplin, S., Flipo, R. M., Chabrefy, L., Mouterde, G., Euller-Ziegler, L., Schaeverbeke, T., Fautrel, B., Saraux, A., Chary-Valckenaere, I., Chales, G., Dernis, E., Richette, P., Mariette, X., Berenbaum, F., Sibilia, J., \& Ravaud, P. (2015). Impact of a nurse-led programme on comorbidity management and impact of a patient self-assessment of disease activity on the management of rheumatoid arthritis: Results of a prospective, multicentre, randomised, controlled trial (COMEDRA). Annals of the Rheumatic Diseases, 74(9), 1725-1733.

Dworkin, B. R., Filewich, R. J., Miller, N. E., Craigmyle, N., \& Pickering T. G. (1979). Baroreceptor activation reduces reactivity to noxious stimulation: Implications for hypertension. Science, 205(4412), 1299-1301.

Fosbol, E. L., Folke, F., Jacobsen, S., Rasmussen, J. N., Sørensen, R., Schramm, T.K., Andersen, S. S., Rasmussen, S., Poulsen, H. E., Køber, L., TorpPedersen, C., \& Gislason, G. H. (2010). Cause-specific cardiovascular risk associated with nonsteroidal antiinflammatory drugs among healthy individuals. Circulation: Cardiovascular Quality and Outcomes, 3(4), 395-405.

Furman, N. V., Dolotovskaya, P. V., Malinova, L. I., \& Reshetko, O. V. (2019). Komorbidnyye sostoyaniya u bolnykh ostrym koronarnym sindromom $\mathrm{v}$ realnoy (povsednevnoy) klinicheskoy praktike [Comorbid conditions in patients with acute coronary syndrome in real (everyday) clinical practice]. Saratov Journal of Medical Scientific Research, 15(3), 821-825 (in Russian).

Grinyuk, V. V., \& Zakharov, V. V. (2019). Komorbidnost arterialnoy gipertenzii i khronicheskogo bolevogo sindroma [Comorbidity of arterial hypertension and chronic pain syndrome]. Effective Pharmacotherapy, 15(34), 46-52 (in Russian).

Grinyuk, V. V., Zakharov, V. V., \& Vakhnina, N. V. (2016). Gipertoniya i porog boli [Hypertension and pain threshold]. Neurology, Neuropsychiatry, Psychosomatics, 8(4), 57-61 (in Russian)

Gromova, M. A., \& Myasoyedova, S. Y. (2014). Arterialnaya gipertenziya, sostoyaniye serdechno-sosudistoy sistemy i kharakteristika boli u bolnykh revmatoidnym artritom [Arterial hypertension, the state of the cardiovascular system and the characteristic of pain in patients with rheumatoid arthritis]. Fundamental Research, 10(4), 651-653 (in Russian).

Haddani, F. Z., Guich, A., Youssoufi, T., Boudhar, E. M., Abouqal, R., Achemlal, L., Allali, F., Bahiri, R., Bouchti, E. I., Maghraoui, E. I., Ghozlani, I., Harzy, T. Hmamouchi, I., Ichchou, L., Mkinsi, O., Niamane, R., \& Hassikou, H. (2020). Comorbidities in rheumatoid arthritis: The RBSMR study. International Journal of Clinical Rheumatology, 15(1), 10-14.

Hitchon, C. A., Boire, G., Haraoui, B., Keystone, E., Pope, J., Jamal, S., Tin, D., Thorne, C., \& Bykerk, V. P. (2016). CATCH investigators. Self-reported comorbidity is common in early inflammatory arthritis and associated with poorer function and worse arthritis disease outcomes: results from the Canadian early arthritis cohort. Rheumatology, 55(10), 1751-1762.

Karateyev, A. Y. (2011). Tselekoksib, etorikoksib, meloksikam i nimesulid: Dostoinstva i nedostatki [Celecoxib, etoricoxib, meloxicam, and nimesulide: Advantages and disadvantages]. Rheumatology, Traumatology, Orthopedics, 1, 9-19 (in Russian).

Karateyev, A. Y. (2012). Obladayut li protivovospalitelnyye preparaty patogeneticheskim deystviyem [Do anti-inflammatory drugs have a pathogenetic effect] Modern Rheumatology, 2, 13-22 (in Russian).

Karateyev, A. Y. (2014). Kolichestvennaya i kachestvennaya otsenka riska oslozhneniy pri ispolzovanii nesteroidnykh protivovospalitelnykh preparatov kak osnova formirovaniya rekomendatsiy po ikh kontrolyu i profilaktike [Quantitative and qualitative assessment of complication risks in using non-steroidal antiinflammatory drugs as a basis for recommendations on their control and practice]. Modern Rheumatology, 1, 64-72 (in Russian).

Karateyev, A. Y., Nasonov, E. L., Ivashkin, V. T., Martynov, A. I., Yakhno, N. N., Arutyunov, G. P., Abuzarova, G. R., Yevseyev, M. A., Kukushkin, M. L., Kopenkin, S. S., Lila, A. M., Lapina, T. L., Novikova, D. S., Popkova, T. V., Re- brov, A. P., Skorobogatykh, K. V., \& Chichasova, N. V. (2018). Ratsionalnoye ispolzovaniye nesteroidnykh protivovospalitelnykh preparatov. Klinicheskiye rekomendatsii [The rational use of non-steroidal anti-inflammatory drugs. Clinical recommendations]. Scientific and Practical Rheumatology, 56, 1-29 (in Russian).

Khimion, L. V., \& Klymas', I. V. (2015). Komorbidnist pry revmatychnykh zakhvoryuvannyakh [Comorbidity in rheumatic diseases]. Ukrainian Journal of Rheumatology, 62(4), 15-18 (in Ukrainian).

Kłodziński, Ł., \& Wisłowska, M. (2018). Comorbidities in rheumatic arthritis. Reumatologia, 56(4), 228-233.

Knyazkova, I. I. (2014). Terapevticheskiy potentsial diklofenaka pri ostrom bolevom sindrome [The therapeutic potential of diclofenac in acute pain syndrome]. Medicine of Ukraine, 1, 37-42 (in Russian).

Kolomoyets, M. Y., \& Vashenyak, O. O. (2012). Komorbidnist' i polimorbidnist' u terapevtychnij praktytsi [Comorbidity and polymorbidity in therapeutic practice]. Ukrainian Medical Journal, 91, 140-143 (in Ukrainian).

Kozachok, N. N., \& Selyuk, M. N. (2010). Lider XXI veka v lechenii bolevogo sindroma [The leader of the XXI century in the treatment of pain syndrome] Ukrainian Medical Journal, 77, 55-58 (in Russian)

Luque, R. A., Redeker, I., Hoffmann, F., Callhoff, J., Zink, A., \& Albrecht, K. (2019). Comorbidities in patients with rheumatoid arthritis and their association with patient-reported outcomes: Results of claims data linked to questionnaire survey. Journal Rheumatology, 46(6), 564-571.

Mantel, Ä., Holmqvist, M., Jemberg, T., Wållberg-Jonsson, S., \& Askling, J. (2017) Long-term outcomes and secondary prevention after acute coronary events in patients with rheumatoid arthritis. Annals of the Rheumatic Diseases, 76, 2017 2024.

Mattia, C., Ciarcia, S., Muhindo, A., \& Colluzzi, F. (2010). Nimesulide: 25 years later. Minerva Medica, 101(4), 285-293.

Moore, A., Makinson, G., \& Chunming, L. (2013). Patient-level pooled analysis of adjudicated gastrointestinal outcomes in celecoxib clinical trials: Meta-analysis of 51,000 patients enrolled in 52 randomized trials. Arthritis Research and Therapy, $15(1), R 6$

Myasoyedova, Y. Y. (2012). Rasprostranennost' i faktory riska arterialnoy gipertenzii pri revmatoidnom artrite [Prevalence and risk factors for arterial hypertension in rheumatoid arthritis]. Scientific and Practical Rheumatology, 2, 31-34 (in Russian).

Naumov, A. V., Tkacheva, O. N., \& Khovasova, N. O. (2019). K voprosu o bezopasnosti nesteroidnykh protivovospalitelnykh preparatov u patsiyentov s serdechno-sosudistym riskom [On the safety of non-steroidal anti-inflammatory drugs in patients with cardiovascular risk]. Therapeutic Archive, 1, 108-113 (in Russian).

Nikitina, N. M., Afanasyev, I. A., Romanova, T. A., \& Rebrov, A. P. (2015). Osobennosti komorbidnosti u bol'nykh revmatoidnym artritom $\mathrm{v}$ raznyye gody nablyudeniya [Features of comorbidity in patients with rheumatoid arthritis in different years of observation]. Modern Rheumatology Journal, 9(1), 39-43 (in Russian).

Oganov, R. G., Denisov, I. N., Simanenkov, V. I., Bakulin, I. G., Bakulina, N. V., Bolduyeva, S. A., Barbarash, O. N., Garganeyeva, N. P., Doshchitsin, V. L., Drapkina, O. M., Dudinskaya, Y. N., Kotovskaya, Y. V., Lila, A. M., Mamedov, M. N., Mardanov, B. U., Miller, O. N., Petrova, M. M., Pozdnyakov, Y. M., Runikhina, N. K., Sayganov, S. A., Tarasov, A. V., Tkacheva, O. N., Urinskiy, A. M., \& Shalnova, S. A. (2017). Komorbidnaya patologiya v klinicheskoy praktike. Klinicheskiye rekomendatsii [Comorbid pathology in clinical practice. Clinical recommendations]. Cardiovascular Therapy and Prevention, 16(6), 5-56 (in Russian).

Ogawa, S., Kuroda, K., Kikuchi, T., Shirai, H., Furusawa, M., Akamine, Y., Satoh, T., Fujii, M., Wakayama, S., \& Koizumi, M. (1991). The effects of lowering of blood pressure on pain sensitivity in spontaneously hypertensive rats. Japanese Journal of Nephrology: Nihon Jinzo Gakkai Shi, 33(11), 1089-1096.

Olyunin, Y. A. (2017). Primeneniye nesteroidnykh protivovospalitelnykh preparatov u bolnykh s vysokim kardiovaskulyarnym riskom [Use of nonsteroidal anti-inflammatory drugs in patients with high cardiovascular risk]. Rheumatology Science and Practice, 55(3), 321-323 (in Russian).

Rodionov, A. V. (2013). Nesteroidnyye protivovospalitelnyye preparaty i arterialnaya gipertenziya: Aktualnost' problemy i taktika vedeniya patsiyentov [Nonsteroidal anti-inflammatory drugs and arterial hypertension: The urgency of the problem and patient management tactics]. Attending Doctor, 2, 25-31 (in Russian).

Roubille, C., Fesler, P., \& Combe, B. (2019). Shifting from a rheumatologic point of view toward patient-centered care in rheumatoid arthritis with an integrated management of comorbidities. Journal Rheumatology, 46(6), 545-547.

Rudyuk, L. I. (2012). Osoblyvosti likuvannya arterialnoyi hipertenziyi pry revmatoyidnomu artryti [Features of treatment of arterial hypertension at rheumatoid arthritis]. Ukrainian Journal of Rheumatology, 48(2), 53-55 (in Ukrainian).

Saavedra, J. (1981). Naloxone reversible decrease in pain sensitivity in young and adult spontaneously hypertensive rats. Brain Research, 209(1), 245-249.

Saratikov, A. S., Vengerovskiy, A. I., \& Prishchep, T. P. (1983). Adyuvantnaya bolezn' (morfologiya, patogenez, eksperimentalnaya terapiya) [Adjuvant disease 
(morphology, pathogenesis, experimental therapy)]. Tomsk University Publishing House, Tomsk (in Russian).

Seredynska, N. M., \& Pavlyuk, H. V. (2013). Kardiotropna diya inhibitoriv tsoh-1 ta tsoh-2 za umov yikh kompleksnoho zastosuvannya $\mathrm{z}$ antahonistom kal'tsiyu dyhidropirydynovoho ryadu na modeli revmatoyidnoho artrytu [Cardiotropic action of tsog-1 and tsog-2 inhibitors under the conditions of their combined application with calcium antagonist of dihydropyridine series in the model of rheumatoid arthritis]. Journal of the National Academy of Medical Sciences of Ukraine, 3, 297-306 (in Ukrainian).

Seredynska, N. M., Khomenko, V. S., Marchenko, O. M., Marchenko-Tolsta, K. S., \& Kyrychok, L. M. (2019). Modelyuvannya arterialnoyi hipertenziyi shlyakhom tryvaloho solyovoho navantazhennya. Monitorynh funktsionuvannya sertsevo-sudynnoyi systemy ta dynamiky intehralnykh pokaznykiv zhyttyediyalnosti u shchuriv (chastyna II) [Modeling of arterial hypertension by long-term salt load. Monitoring of the cardiovascular system functioning and the dynamics of integrated vital signs in rats (part II).]. Pharmacology and Drug Toxicology, 13(3), 203-212 (in Ukrainian).

Seredynska, N. M., Kyrychok, L. M., Mokhort, M. A., \& Pavlyuk, H. V. (2013). Porivnyalna otsinka protyzapalnoyi aktyvnosti nimesulidu, dyklofenaku ta amlodypinu za adyuvantnoho artrytu [Comparative assessment of the anti-inflammatory activity of nimesulide, diclofenac and amlodipine in adjuvant arthritis]. Pharmacology and Drug Toxicology, 2, 65-69 (in Ukrainian).

Seredynska, N. M., Mokhort, M. A., \& Kyrychok, L. M. (2014). Bolyova chutlyvis ta adekvatnist yiyi otsinky za testom "tail flick" u bilykh shchuriv [Pain sensitivity and adequacy of its assessment by the test "tail flick" in white rats]. Pharmacology and Drug Toxicology, 39(3), 45-51 (in Ukrainian).

Shuba, N. M., Voronova, T. D., \& Kokunov, Y. O. (2018). NPVS-riski i vybor bezopasnoy terapii [NSAID risks and the choice of safe therapy]. Ukrainian Journal of Rheumatology, 1, 18-22 (in Russian).
Sitsen, J., \& de Jong, W. (1983). Hypoalgesia in genetically hypertensive rats (SHR) is absent in rats with experimental hypertension. Hypertension, 5(2), 185-190.

Skorokhodov, A. P., \& Polyanskaya, O. V. (2013). Nimesulid: Vozmozhnyye mekhanizmy deystviya, pokazaniya $\mathrm{k}$ naznacheniyu, osobennosti primeneniya $\mathrm{v}$ klinicheskoy praktike [Nimesulide: Possible mechanisms of action, indications for use, features of application in clinical practice]. Russian Medical Journal, 21(30), 1546-1548 (in Russian).

Trelle, S., Reichenbach, S., Wandel, S., Hildebrand, P., Tschannen, B., Villiger, P. M., Egger, M., \& Juni, P. (2011). Cardiovascular safety of non-steroidal antiinflammatory drugs: Network meta-analysis. BMJ, 342, c7086.

Turesson, C. (2016). Comorbidity in rheumatoid arthritis. Swiss Medical Weekly, 146, w14290.

Wendel, O., \& Bennett, T. (1981). The occurrence of analgesia in an animal model of hypertension. Life Sciences, 29(5), 515-521.

Widdifield, J., Paterson, J. M., Huang, A., \& Bernatsky, S. (2018). Causes of death in rheumatoid arthritis: How do they compare to the general population? Arthritis Care and Research (Hoboken), 70(12), 1748-1755.

Wojciechowska, M., Wątroba, M., Ciużyńska, G., Bral, M., \& Szukiewicz, D. (2013) Ischaemic heart preconditioning in rats with adjuvant-induced arthritis Kardiologia Polska, 71(8), 839-844.

Yeliseyev, M. S. (2016) Nimesulid v lechenii ostroy boli v revmatologicheskoy praktike: pochemu nisha po-prezhnemu zanyata [Nimesulide in the treatment of acute pain in rheumatological practice: why the niche is still busy]. Medical councilium, 17, 110-112 (in Russian).

Zhuravleva, M. V., Kukes, V. G., Prokofyev, A. B., \& Serebrova, S. Yu. (2016) Ratsionalnoye primeneniye NPVS - balans effektivnosti i bezopasnosti (obzor literatury) [Rational use of NSAIDs - balance of efficacy and safety (literature review)]. International Journal of Applied and Fundamental Research, 6(4), 687-696 (in Russian). 